\title{
The Path Research of International Education in Universities
}

$$
\text { Cuiying } \mathrm{Li}^{1, \mathrm{a}^{*}} \text {, Yi Cheng }{ }^{2, \mathrm{~b}} \text { and Han } \mathrm{Li}^{3, \mathrm{c}}
$$

${ }^{1}$ Center of Educational Reform and Teaching Quality Evaluation, Bohai University, Jinzhou 121013, China

${ }^{2}$ College of Mathematics and Physics, Bohai University, Jinzhou 121013, China

a ${ }_{\text {Lncy999@126.com, }}{ }^{\mathrm{b}}$ chengyi407@126.com, ${ }^{\mathrm{c}}$ 15566527260@163.com Keywords: Economic globalization; Teaching reform; Internationalization path; Education
internationalization

\begin{abstract}
Economic globalization is the objective trend and the most notable features of economic development in the world undoubtedly, and brings profound influence for the world's economic and social development. The economic globalization promotes the cross-border flows of goods, services, technology, knowledge, information, funds and human resources elements and global configuration at the same time, not only creates the conditions for higher educational internationalization, but also accelerates the development of the internationalization of higher education.

The author through the access and organize data to analysis the principle of the development of higher education internationalization in our country, put forward the strategies of the development of higher education internationalization, hope to provide beneficial reference for the development of colleges and universities.
\end{abstract}

\section{The Basic Principles of the Development of Higher Education Internationalization on Our Country}

Internationalization of higher education is a inevitable requirement not only for the regional social economy development, also the regional city development, as an important way of higher education in their own development and breakthrough, therefore, we should determine the development of higher education internationalization strategy according to the following principles, in order to ensure the internationalization of higher education in the right direction.

The Principle of Equality. Equality is one of the most important principle that the higher education internationalization should uphold. Currently, due to the different level of economic development, the level of education is very uneven. At present, international communication platform between our domestic universities and foreign universities is inequality, our country generally learn lessons from other countries, this kind of practice is not conducive to motivate the innovation of higher education in our country. Therefore, regional development of higher education internationalization strategy should insist on the principle of equality.

Bidirectional Principle. Bidirectional principle mainly should pay attention to internationalization of higher education and refer to the activities of the two-way interaction. Not only should be teachers and students sent to college to study abroad, but also should actively we invite some foreign teachers and students to study in domestic, to promote mutual understanding (see [1]). At the same time, our country should take care of the quality of foreign students, we should not only pursuit the economic interests, but also exchange, reciprocity, mutual understanding, mutual growth.

Diversified Principle. The current higher education internationalization are reaching the "westernization" "Americanization" or even "Europe", but when we make the internationalization of education policies, not only should focus on the education of economic developed countries, also should attach great importance to the nation of culture deeply. We suck all can use the good resources, speed up the internationalization of regional higher education in the long term.

Underlying Principles. Our international communication not only is limited by language and writing skills of learning, we should be fully integrated into the international content in the introduction, development and application of each phase of the project, especially study the Chinese 
nation's profound traditional culture, etc., let the participants study and communicate deeply from various aspects. In this regard, the European Union established the Erasmus Mundus project of communication network platform is worthy of our study. The Erasmus Mundus project in foreign universities builds special network, promotes the knowledge innovation and exchange of experience, and improve the quality of international education and exchange.

\section{Building Strategies for Promoting the Development of the Chinese Higher Education Internationalization}

Policies and Regulations Support. Foreign developed countries on higher education cooperation and exchange of important premise to establish a standardized and scientific system of higher education. In order to realize the internationalization policy stability and continuity, most developed countries definite related requirements and regulations usually in the form of policies, laws, regulations and legislation, make its rise to the national willing, which has the legal effect. It is easy to find that internal power of the development of higher education internationalization source countries. When making policies and regulations for the internationalization of higher education in our country, the national government at all levels should intervene and optimize the distribution and structure of regional higher education through policy and administrative, create basic conditions for the balanced development of the internationalization of education in colleges and universities, at the same time, combine with the urbanization process, make the internationalization of education work and economic coordinated development, finally realizes the comprehensive development of higher education.

Putting More Money in the Internationalization of Higher Education. At present, education funding of colleges is shortage and the sources of the single, money for education internationalization development is insufficient. Both states and government should pay more attention to this problem, and make some measures to support effectively for education internationalization development funds, take into account the differences of different regional higher education development (see [2]). Under the vision of education fairness, states properly give more investment for the central and western regions and provinces where higher education are not developed, to ensure the education internationalization educational condition and scale of synchronous growth, and to achieve the overall development of the internationalization of education.

Promoting Chinese Language and Construction of Chinese International Test Center. Learning Chinese is to understand and learn the Chinese culture medium of language, universities should fully motivate the advantage resources, and send Chinese teachers to teach Chinese language surrounding countries and regions of colleges and universities, successfully spread the national traditional culture, and improve the influence of Chinese language in the world. At the same time, our country step up efforts to set up the domestic Chinese language test center in colleges and universities, colleges and universities can consult exam system from the TOEFL and IELTS, and set up the international Chinese overseas test center. Foreigners who go through the examination can obtain qualification certificates issued by the Chinese language test center, such a series of measures is to make our related department to recruit foreign students, to hire foreign staff who have to follow the basis and principles, these measures make the relevant work be on the following basis and principles.

Characteristics of Education Internationalization Path That Run a School, Basing on the Local and National Features. Colleges and universities should build characteristic specially, and highlight the characteristics and advantages of disciplines development, to promote the development of international education (see [3]). Colleges and universities should combine the characteristic discipline with traditional advantage ones on the basis of traditional advantage disciplines for innovation and breakthrough, to construct professional disciplines up to the international standard. In addition, the emerging disciplines provides conditions for creating the characteristic discipline in colleges and universities, the related disciplines can cross each other, and support each other to form characteristic, besides, gradually form the system of coordinated 
development in the traditional and emerging disciplines. Finally, the characteristic discipline is constructed in universities basing on the realistic demand of the area.

Multi-level Educational Cooperation and Exchange. Colleges and universities should actively explore cooperating projects, actively develop the project of cooperating consciousness, and carry out project cooperating with foreign universities, to deepen the international cooperation. In addition, we still should pay attention to the project of cooperation to promote the university teaching and scientific research level, and to enhance the school's overall education level. Colleges should continue to deepen the domestic-foreign cooperation in running schools, and seek a new form of domestic-foreign cooperation, and enrich the forms and contents of this cooperation. The regional government should give corresponding policy to guidance and support the international project cooperation, and provide favorable policy to support the exchanges and cooperation of regional higher education international project. We provide students with more security and attract students to learn in colleges and universities.

\section{Acknowledgments.}

Research is supported by the NNSF of China(No.11401042, 11301541) and the Five-Year planning of higher education research higher education institute of Liaoning Province

(No.GHYB160080).

\section{Reference}

[1] H.D.Wit: A Historical Comparative and Conceptual Analysis(Greenwood Press) , London, 2002.

[2] H.A. Goldstein: The Entrepreneurial Turn and Regional Economic Development Mission of Universities, The Annals of Regional Science, 44(2010)83-84.

[3] S.C. Chen: The Causes and Countermeasures of Local University International Analysis, 2(2013) 14-15.

[4] ]P. X. Ning,Y. Ying. AP science project development and reform of science curriculum in high school in China. Theory and Practice of Education, 8(2009)8-10.

[5] Bransford, K. Cheng la et al translation, How people learn: brain, psychology, experience and school Shanghai: East China Normal University Press, 2002, 17-18.

[6] R. Sawyer Keith. Cambridge Handbook of learning science. Beijing: Educational Science Publishing House, 2010.

[7] D. Q. Huang, Y. M. Jia, Study on the development of American learning science Studies in foreign education, 38(2011)91-96.

[8] J. Kolodner, The Learning sciences: Past, present, future[J]. Educational Technology, 5(2004)34-40.

[9] J. Kolodner, The "neat" and the "scruffy" in promoting learning from analogy: we need to pay attention to both. The Journal of the learning Sciences, 11(2002)139-152.

[10]R. Mayer, Introduction to multimedia learning. In Mayer, R. The Cambridge Handbook of Multimedia Learning. Cambridge University Press, 2005.

[11] Polman, Dialogic activity structures for project-based learning environments. Cognition and Instruction, 22(2004)431-466.

[12] M. C. Linn, Designing computer learning environments for engineering and

[13] computer science: The scaffolded knowledge integration framework, Journal of

[14] Science Education and Technology, 4(1995)103-126. 